\title{
INNOVATION OF POLISH FAMILY AND NON-FAMILY BUSINESSES
}

\author{
Teresa KRAŚNICKA \\ University of Economics in Katowice; teresa.krasnicka@ue.katowice.pl, ORCID: 0000-0002-6862-2901
}

Purpose: The study aimed to identify differences in the level of innovation of the two types of firms - family (FB) and non-family (NFB) - and understand how the expectations of the management and/or business owners vary regarding the impact of innovations on business performance.

Design/methodology/approach: Research questions were formulated based on the review of the findings of the surveys that compared innovation in family and non-family firms worldwide. Then, empirical research was conducted in 334 family and non-family firms in Poland.

Findings: The findings do not confirm significant differences in the level of product innovation between FB and NFB. On the other hand, they point to a higher level of innovation measured with the number of process innovations in NFB. Research shows that firms rate the degree to which the expectations of innovation effects were fulfilled relatively low in both types of firms. Research limitations/implications: The applied measurement of the level of innovation according to the number of implemented innovations does not take into account their qualitative aspect, whether they are radical or incremental. The survey (questionnaire and interview) was based solely on the number of innovations declared as implemented by the respondents.

Practical implications: The survey findings should inspire managers of family and non-family firms to analyze both the expected effects of the implementation of a particular type of innovation and to assess its actual outcomes.

Social implications: Studies show that FB are not less innovative when it comes to implementing new or modified products and services. This contradicts both the opinions and some research results about the conservatism of FB or their stronger orientation towards family goals at the expense of a firm's growth.

Originality/value: This comparative study on FB and NFB innovation fills a gap in the area where knowledge concerning this issue is still scarce in Poland.

Keywords: family business, non family business, innovation, product innovation, business process innovation.

Category of the paper: Research paper. 


\section{Introduction}

Interest both in business innovation and in family businesses (FB) as opposed to non-family businesses (NFB) is fully justified by the importance of both issues. Innovation is one of the key factors in the competitiveness of enterprises and economies, while family businesses, according to all estimates, dominate in the structure of entities running economic activity practically in most countries. Simultaneously, the existing knowledge on FB points to their certain characteristics that distinguish them from businesses that are not family-owned, nor is the family involved in management. Therefore, family businesses attract unwavering interest of researchers, who undertake to explore various aspects of their operations (De Massis and Foss, 2018; Neubaum, 2018). Also in Poland, FB come under increasingly extensive scientific investigation, including research on their innovation, but research gaps still exist, which encourages further examination. Knowledge concenring differences in innovation of FB compared to NFB is still limited. The question about the existence of these differences and their underlying causes is still open, as studies conducted in different countries do not provide a conclusive answer, and in Poland the deficit of research into this issue is particularly evident. Therefore, the article aims to present the results of the survey which are to enrich the knowledge on innovation of family and non-family businesses, measured with the number of different types of innovations implemented in the last three years. The following research questions were formulated:

1. is the level of innovation in family businesses lower than the one in non-family businesses, as may be concluded from some studies conducted worldwide?

2. do such variables as the size of a firm, its business profile and its age cause differences in the level of innovation?

3. do managers/business owners differ in their assessment of the effectiveness of the innovations implemented - were their expectations concerning improved business performance fulfilled?

\section{Characteristics of family businesses}

Family businesses are the subject of intensive research with primary focus on identifying family influence, family involvement in the business and its management - on business performance and other aspects of business operations. This need for research is manifested not only in family business journals (such as Family Business Review), but also in special issues of peer-reviewed journals on entrepreneurship. Similarly, Polish scientific periodicals dedicate 
whole issues to family business studies ${ }^{1}$. On the one hand, studies on family businesses stem from their role in the economy and, on the other hand, from their unique nature. FB are attributed a number of characteristic features such as:

- family management of the business, which, in consequence, creates unique bonds and interdependencies between family members and the business; this can generate problems in terms of equal treatment of employees who are not family members,

- succession based on a chosen strategy, the aim of which is to maintain continuity of family management of the business,

- aspiration to remain independent,

- orientation towards financial and non-financial goals,

- a variety of goals pursued by family members working in the firm integrated into the business (making a decent living, developing a career path, the opportunity to fulfil higher-level needs, such as prestige and self-actualization),

- capital of the business in the hands of the family (one or more),

- financing initial growth with family-owned capital, such as owners' property, newly acquired property through marriage, etc. (cf. Sułkowski and Marjański, 2009; Safin, 2007).

An important research direction involves comparative analyses of FB vs. NFB, concerning selected issues, for example, the level of innovation (Ahluwalia, Mahto, and Walsh, 2017). These studies are based on the assumption that FB differ from NFB to a significant extent, hence the need to define the former and identify the characteristics distinguishing them from other entities forming the structure of the economy. Literature offers no single definition of FB and researchers tend to adopt definitions that correspond to the objectives of a study, its context, etc. There is universal agreement that it difficult to make a clear distinction between FB and NFB and awareness that such a dichotomous approach can certainly lead to errors in qualification, as pointed out by researchers in this area (e.g. Steeger and Hoffmann, 2016). According to Habbershon and Williams (1999), FB are unique bundles of resources and capabilities which result from interactions between the family and the firm. Generally, however, researchers tend to use such criteria as the family's majority ownership, family management and control of the business, and, as Klein points out (2000), failure to meet one of these criteria must be compensated by the others. The criterion frequently adopted for classifying a firm as FB is only majority ownership or self-identification by the founder and/or manager (cf. Steeger and Hoffmann, 2016). Polish authors also recognize a variety of criteria as constitutive of FB, stressing that the most frequent ones include ownership, control over the firm (as a consequence

\footnotetext{
${ }^{1}$ One example is the journal „Przedsiębiorczość i Zarządzanie”, which publishes entire issues dedicated to family businesses. In 2016, 2017 and 2018, three-part publications were released, which were dedicated to family businesses in Poland and other countries.
} 
of ownership), and management (cf. Surdej and Wach, 2010) $)^{2}$. Moreover, FB research often adopts such a definition that corresponds to the needs of a particular research project (cf. Steinerowska-Streb, 2015). Although knowledge about FB has grown significantly (De Massis and Foss, 2018), it is still difficult to define these firms in an unequivocal manner and a variety of issues are yet not clearly addressed, for example, innovation.

\section{Current state of research on innovation in family businesses}

Attempts at defining the key concept of innovation, especially in terms of innovation measurement, still reveal significant differences, which - in the research context - relate mainly to research objectives and other methodological assumptions. Literature provides numerous reviews concerning the definition of the concept and its typologies, authored both by Polish (Pichlak, 2012) and foreign researchers (De Massis, Frattini and Lichtenthaler, 2013). Enterprise innovation is understood as a firm's ability and willingness to create new solutions, adapt the existing ones, and pursue their implementation. The construct is of multidimensional nature, in its fullest form - three-dimensional, embracing not only an organization's willingness to generate (or adapt) innovations, but also its ability and readiness to take risks related to the implementation of new solutions (Pichlak, 2012, pp. 35-36). Research on business innovation uses a variety of measures, such as innovation expenditure, the number of patents, and the number of innovations implemented in a particular period of time (for example, three years).

Based on the extant research, the determinants of FB innovation activity and related processes appear to be extremely complex. The family's impact on the firm owned may be positive or negative. On the one hand, researchers point to the long-term orientation of family businesses, owned and managed by family members, which may encourage investing in innovation, despite the risk involved. As a result, innovation can become an important factor ensuring the survival of the firm and its transfer to the next generation (Jaskiewicz, Combs and Rau, 2015). Other studies, on the other hand, emphasize a kind of conservatism of family businesses and caution in making decisions carrying relatively high risk. Undoubtedly, decisions concerning the implementation of innovations, especially technological ones, involve such risk. This conservatism has many causes and results from the desire to pass on the firm to the next generation and achieve not only economic but also non-economic goals. This increases the fear of both technological (especially with new products or technologies) and financial failure. These circumstances translate into relatively low R\&D expenditure and the avoidance of technologically advanced innovations, which are characterized by a relatively higher risk of

\footnotetext{
${ }^{2}$ Surdej and Wach (2010) present a wide review of family business definitions based on different criteria.
} 
failure. Some studies confirm the low innovativeness of family businesses (Matzler, et al., 2015). Furthermore, Bendig, et al. (2020) point out not only the depth of family involvement in business as an important determinant of FB innovation activity, but also the nature of innovations implemented by FB - whether they are technological inventions or market innovations.

At the same time, FB are observed to manifest a variety of strengths in the context of undertaking innovation activity. It is emphasized that family members running FB can make better, more rational use of the limited resources they have, especially financial resources allocated to innovation (De Massis et al., 2018). Duran et al. (2016) formulated the principle of FB performance in this regard as: "doing more with less". Furthermore, some researchers argue that FB can make more effective use of extensive knowledge, often accumulated over several generations, concerning products, formulas, technologies, but also market knowledge and close customer relationships (Bendig et al., 2020).

Studies are also conducted on the tension between capacity to engage in R\&D activity and reluctance to invest in it. Family business researchers describe this phenomenon as "willingness-ability paradox" (De Massis et al., 2015). Some studies confirm that if this scepticism of family members can be overcome, FB can be more effective in innovation activity than NFB, assuming similar expenditure (Duran et al., 2016). The "willingness-ability paradox" is examined from different points of view, as its significance may vary depending on the type of innovation under consideration (Bendig et al., 2020). Studies are undertaken to explain its underlying causes. Rondi et al. (2019), for example, propose the concept of family business innovation posture, which embraces two factors - risk-taking propensity and tradition attachment - and can account for the diversity of family attitudes to innovation. The above review shows that research on the impact of broadly understood family involvement in business (assessed using various measures) on innovation, its effects and, finally, FB performance does not provide a conclusive answer. Similarly, studies conducted in our country do not provide an unequivocal answer to the question on how family involvement affects FB performance (cf. Kraśnicka, Ingram, and Głód, 2019). The results of the surveys on FB innovation to date are also inconclusive when comparing family firms with non-family firms. Therefore, the comparative trend presents both the results that identify FB as less innovative than nonfamily businesses and those that provide empirical evidence of their higher innovativeness compared to NFB. This current of research is based on empirically verified theories explaining relationships between family involvement in FB management and innovative activity, measured in particular, on the one hand, with investment expenditure on innovation and, on the other hand, with the results expressed as the number of innovations implemented, patents obtained, etc. Therefore, the comparison of FB and NFB innovation takes into account these numerous differences that may occur between the two types of firms, relating to the factors determining 
the level of innovative activity and its effects. Differences in investment expenditure on innovation and knowledge resources may have a positive impact on the relevance of innovations (measured with the number of market-relevant product announcements), but a negative influence on a firm's number of inventions (measured with the number of patents) (Bendig et al., 2020). Firms may also vary in terms of social capital as a determinant of innovation (Chrisman et al., 2015). Literature also presents research results showing that family firms are more innovative than non-family firms (Kammerlander and van Essen, 2017). N. Kammerlander and M. van Essen collected all available publications and research papers that addressed innovation in $\mathrm{FB}$ and $\mathrm{NFB}$, in particular those relating to investment in innovation (measured with $R \& D$ expenditure) and its effectiveness expressed with new products, patents and patent citations. The publications embraced 108 empirical studies conducted in 42 countries in the years 1981-2012. Meta-analysis yielded the following results: family firms invest less in innovation than other (public and private) firms that are not family owned. On average, FB have a lower R\&D budget than other firms of similar size, but at the same time FB are more efficient in terms of innovation processes (every dollar invested in R\&D makes a greater return measured with the number of patents, the number of new products, or revenues generated by new products). Based on the results, N. Kammerlander and M. van Essen (2017) concluded that FB had a higher level of innovation than other firms. Other researchers also conducted comparative studies of FB and NFB innovation (Classen et al. 2014). Their study in Germany revealed significant differences between family and nonfamily small and medium-sized businesses at every stage of the innovation process. In the sample, non-family SMEs were more likely to invest in innovation than family firms of the same size. In terms of innovation performance, however, it turned out that family SMEs were at least as effective as non-family SMEs in product innovation and on average more effective than non-family SMEs in process innovation. Moreover, these results confirm the view that family SMEs strive to maximize the probability of long-term survival by choosing positive but less intensive innovation investments compared to non-family SMEs (Classen et al., 2014).

The above review of research results concerning, in particular, the comparison of FB and NFB innovation, shows that its analysis - due to high complexity - is difficult, which is related to its numerous determinants, especially in FB. The research results so far provide various answers to the question concerning the level of innovation in FB compared to the one in NFB. Undoubtedly, the differences in the evaluation of innovation in these two types of firms may also stem from different methods of measuring it used in research as well as independent variables the influence of which on innovation is examined. 


\section{Research method}

In the light of the existing research gap concerning FB innovation compared to NFB innovation in Poland, the following research questions were formulated:

1. is the level of innovation in family businesses lower than the one in non-family businesses, as may be concluded from some studies conducted worldwide?

2. do such variables as the size of a firm, its business profile and its age cause differentiation in the level of innovation?

3. do managers/business owners differ in their assessment of the effectiveness of the innovations implemented - were their expectations concerning improved business performance fulfilled?

The key methodological procedure in this study is the selection of criteria to distinguish family businesses from other firms, which is difficult, especially in the case of micro, small and medium-sized firms, as FB are mostly firms classified as SMEs. As indicated above, various operational definitions of FB are adopted for the purposes of research. Family businesses are defined as those that employ at least two family members and the family is the majority owner of the firm (Naldi et al., 2013; Reay, Jaskiewicz, and Hinings, 2015). The definition that is often used for research purposes includes ownership and/or management with the intention of developing and pursuing a business vision by a dominant coalition of members of one family (or several families) to make the firm sustainable across future generations of the family (or families) (Chua, Chrisman and Sharma, 1999, p. 25). Taking into account this large variety of adopted criteria as well as their number (cf. Roessl, Fink, and Kraus, 2010) ${ }^{3}$, this study assumed that FB are firms in which family members directly manage the business (they are members of the board) and have a share of ownership ensuring control over the business ( $20 \%$ and more). Additionally, it was assumed that at least one other family member participates in the activities of the business.

As indicated above, different indicators are used to measure innovation. These may include innovation expenditure, $R \& D$ expenditure, or the number of patents, although these indicators are considered of little use in the examination of firms among which micro and small businesses dominate (Ahluvalia, Mahto and Walsh, 2017) and others are used, for example, the number of innovations implemented in a certain time period (e.g., De Massis et al., 2013). Such measures are also suggested in the Oslo Manual, both in the third (2008) and fourth editions (2018). The fourth edition of the Oslo Manual (2018) distinguished only two main types of business innovation: product innovation (understood as the implementation of a new or improved product or service) and business process innovation (understood as new or improved processes, concerning one or more functions of the firm, which are significantly different from those previously implemented in the firm). Business process innovations include new or improved

\footnotetext{
${ }^{3}$ Roessl, Fink and Kraus (2010) adopted as many as five criteria for identifying family businesses.
} 
processes for manufacturing (service provision), distribution and logistics, marketing and sales, information and communication, and administration and management. The importance of innovation concerning management processes, methods and structures, the so-called management innovation, was long emphasized (Kraśnicka, Głód and Wronka-Pośpiech, 2016), which was reflected in the fourth edition of the Oslo Manual (2018). For the purposes of the survey presented here, the definitions of product and process innovations were adopted in accordance with the Oslo methodology. Based on its principles, the following measures of innovation were applied:

- the number of product (or service) innovations implemented in the last three years;

- the number of business process innovations, including the number of innovations in:

1. manufacturing processes;

2. logistics and distribution;

3. marketing and sales;

4. information and communication;

5. administration and management - implemented in the last 3 year.

To fulfill the aims the purposeful sampling based on the following criteria was used. The invitation to participate in the research was sent to 600 companies in all 16 provinces of Poland ${ }^{4}$. In the sample's selection, the familiness criterion was taken into account so that the sample had equal numbers of family and non-family enterprises. Besides, the selection of the sample took into account the criteria of the size and profile of activity, so that all categories of enterprises by size (based on the number of employees) and selected four business profiles (trading, service, manufacturing, mixed) were equally represented in the sample. Ultimately, the invitation to participate in the research was accepted by 343 companies, and 334 companies were qualified for the analysis (mainly due to incomplete answers, etc.).

The survey was carried out partly with a questionnaire interview, conducted by an interviewer, and partly with a survey questionnaire. The questionnaire contained, among other things, two special questions concerning the subjective opinion of the respondent on to what extent the implemented innovations (product and process innovations separately) fulfilled the expectations of the management and/or owners of the firm in terms of imporved business performance (sales and/or profit). A 5-point Likert scale was used for this subjective assessment of innovation effects.

Descriptive statistics, including averages and standard deviation, were used to analyze the results.

\footnotetext{
${ }^{4}$ The survey was carried out by a specialized unit - the Center for Research and Knowledge Transfer at the University of Economics in Katowice. The Center uses its own databases of firms.
} 


\section{Population characteristics of the respondent firms}

The survey covered 334 firms, divided into family (164 FB) and non-family (170 NFB) businesses. In terms of core activity, the population was slightly dominated by service providers (35\%) and firms with a mixed business profile (31\%). In terms of size, measured with the number of employees, small businesses (with up to 49 employees) were the most numerous and accounted for more than $48 \%$ of the total number of respondents. The second largest group included microfirms, which made up $14 \%$ of the entire sample. In terms of age, on the other hand, the largest group was the firms operating for 11 to 20 years (over 39\%), while the least numerous group included the firms existing for over 30 years $(14 \%)$.

As for differences between family and non-family firms according to these three characteristics, they are generally insignificant, although they did occur in several cases. In terms of core activity, slightly more NFB were service providers (66 NFB to 51 FB); on the other hand, more FB specialized in manufacturing (48 to 25). When the size is taken into account, only very large firms - employing over 500 people - were predominantly non-family owned (16 to 6). The analysis of the two populations of firms based on their age reveals that only the first "age" category - up to 10 years of operation - was strongly dominated by NFB (49 to 25). Table 1 presents detailed data concerning, among others, the structure of the respondent population of firms.

\section{Table 1.}

Innovation and the evaluation of its effects by profile, size and age of respondent firms

\begin{tabular}{|c|c|c|c|c|c|c|c|c|c|c|c|c|}
\hline \multirow[t]{2}{*}{ 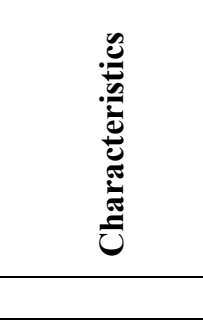 } & \multirow[t]{2}{*}{ 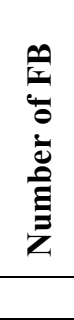 } & \multirow[t]{2}{*}{$\frac{\infty}{e^{\circ}}$} & \multirow[t]{2}{*}{ 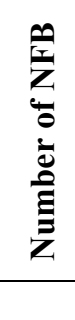 } & \multirow[t]{2}{*}{$\begin{array}{l}\frac{D}{Z} \\
\partial^{\circ}\end{array}$} & \multicolumn{2}{|c|}{ 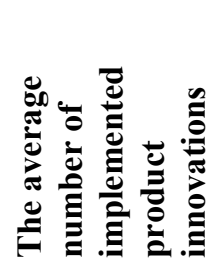 } & \multicolumn{2}{|c|}{ 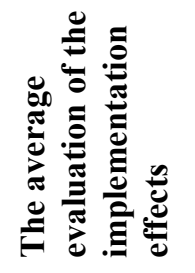 } & \multicolumn{2}{|c|}{ 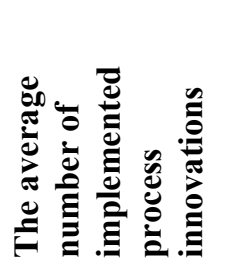 } & \multicolumn{2}{|c|}{ 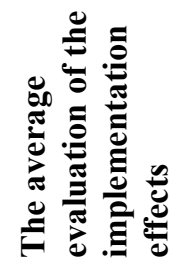 } \\
\hline & & & & & FB & NFB & FB & NFB & FB & NFB & FB & NFB \\
\hline 1. Profile: & 164 & 100 & 170 & 100 & 3.6 & 3.3 & 2.6 & 2.5 & 19.7 & 21.2 & 2.9 & 2.96 \\
\hline /1/Trading & 18 & 11 & 22 & 13 & 2.25 & 2.0 & 2.55 & 2.41 & 14.3 & 14.70 & 2.69 & 2.95 \\
\hline /2/Service & 51 & 31 & 66 & 39 & 2.96 & 3.23 & 2.75 & 2.46 & 16.79 & 21.84 & 2.85 & 2.87 \\
\hline $\begin{array}{l}\text { /3/Manu- } \\
\text { facturing }\end{array}$ & 48 & 29 & 25 & 15 & 3.98 & 4.6 & 2.47 & 2.67 & 22.53 & 30.26 & 3.12 & 3.29 \\
\hline /4/Mixed & 47 & 29 & 57 & 34 & 4.51 & 3.27 & 2.5 & 2.42 & 21.94 & 18.94 & 2.92 & 2.92 \\
\hline $\begin{array}{l}2 . \text { Size by } \\
\text { the number of } \\
\text { workers }\end{array}$ & 164 & 100 & 170 & 100 & 3.63 & 3.29 & 2.57 & 2.47 & 19.68 & 21.18 & 2.91 & 2.96 \\
\hline Up to 9 & 26 & 16 & 21 & 12 & 1.87 & 2.69 & 2.32 & 2.29 & 12.48 & 12.1 & 2.52 & 2.5 \\
\hline $10-49$ & 75 & 46 & 87 & 51. & 3.03 & 2.83 & 2.48 & 2.40 & 17.33 & 17.84 & 2.87 & 2.93 \\
\hline $50-99$ & 24 & 15 & 17 & 10 & 3.19 & 3.76 & 2.7 & 2.53 & 17.10 & 26.53 & 2.92 & 2.9 \\
\hline $100-249$ & 19 & 12 & 17 & 10 & 4.76 & 2.94 & 2.69 & 2.47 & 22.26 & 22.44 & 3.15 & 2.96 \\
\hline $250-499$ & 14 & 9 & 12 & 7 & 6.32 & 5.71 & 2.83 & 3 & 37.07 & 35.75 & 3.5 & 3.55 \\
\hline 500 and more & 6 & 4 & 16 & 9 & 10.5 & 4.59 & 3 & 2.6 & 41.75 & 33.34 & 3.5 & 3.31 \\
\hline
\end{tabular}


Cont. table 1

\begin{tabular}{|l|l|r|l|r|r|r|r|r|r|r|r|r|}
\hline 3. Age & $\mathbf{1 6 4}$ & $\mathbf{1 0 0}$ & $\mathbf{1 7 0}$ & $\mathbf{1 0 0}$ & $\mathbf{3 . 6 2 5}$ & $\mathbf{3 . 2 9}$ & $\mathbf{2 . 5 6}$ & $\mathbf{2 . 4 7}$ & $\mathbf{1 9 . 6 8}$ & $\mathbf{2 1 . 1 8}$ & $\mathbf{2 . 9 3}$ & $\mathbf{2 . 9 6}$ \\
\hline Up to 10 years & 25 & 15 & 49 & 29 & 3.62 & 2.91 & 2.67 & 2.53 & 14.8 & 17.58 & 2.88 & 2.84 \\
\hline 11-20 years & 65 & 40 & 67 & 39 & 3.72 & 3.41 & 2.52 & 2.44 & 19.97 & 20.36 & 2.96 & 2.96 \\
\hline 21-30 years & 47 & 29 & 33 & 19 & 3.6 & 3.55 & 2.58 & 2.45 & 22.51 & 23.77 & 2.9 & 3.07 \\
\hline $\begin{array}{l}\text { More than 30 } \\
\text { years }\end{array}$ & 27 & 16 & 21 & 12 & 3.44 & 3.36 & 2.57 & 2.5 & 18.56 & 28.14 & 2.97 & 3.05 \\
\hline
\end{tabular}

Source: own elaboration.

\section{Presentation of the results}

In line with the objectives of the study, we first analyzed the level of innovation of family and non-family firms, measured with the number of both product and business process innovations, implemented in the last three years. Based on the results (Table 1), it can be concluded that innovation in the two groups of firms is at a similar level and amounts, on average, to 3.6 product innovations per FB and 3.3 per NFB. The innovation index shows a slightly greater difference for process innovations, as it amounts to 19.7 in FB and 21.2 in NFB.

Table 2 shows that a higher percentage of FB than NFB did not implement any product innovations $-17 \%$ of FB to $11 \%$ of NFB. The largest number of respondents implemented between two and five product innovations in the past three years, 53\% of FB and slightly more NFB $-57 \%$.

Table 2.

Quantitative characteristics of product innovations implemented in family and non-family firms

\begin{tabular}{|l|r|r|r|r|}
\hline The number of implemented innovations & The number of FB & \% FB & The number of NFB & \% NFB \\
\hline No implementation & 28 & $17 \%$ & 18 & $11 \%$ \\
\hline 1 & 27 & $16 \%$ & 32 & $19 \%$ \\
\hline 2 & 30 & $18 \%$ & 42 & $25 \%$ \\
\hline $3-5$ & 57 & $35 \%$ & 54 & $32 \%$ \\
\hline $6-10$ & 10 & $6 \%$ & 20 & $12 \%$ \\
\hline $11-20$ & 9 & $5 \%$ & 3 & $2 \%$ \\
\hline More than 20 & 3 & $2 \%$ & 1 & $1 \%$ \\
\hline
\end{tabular}

Source: own elaboration.

In the case of business process innovations implemented in FB (Table 3), the lowest percentage $-10.4 \%$ - did not implement marketing innovations, while the highest $(25 \%)-$ did not implement administration and management innovations. A similar pattern was confirmed for NFB. Most FB (46-53\%) implemented two to five process innovations; only in the case of information and communication innovations the largest percentage of firms (43\%) implemented one or two. A similar result was obtained for NFB, where, too, the largest number of firms (41-49\%) implemented two to five innovations, except for administration and 
management innovations. In this case, the largest number of firms (44\%) implemented one or two innovations of this type.

The analysis of the research results taking into account the three selected characteristics of FB and NFB revealed that in trading and service firms the adopted product innovation indicator was lower than the average (Table 1). Moreover, this innovation indicator was higher than its average value in firms with a manufacturing and mixed profile, with the highest values reported for NFB with a manufacturing profile (4.6) and FB with a mixed profile (4.5). Slightly greater variation in the level of product innovation was found in firms of different sizes, both FB and NFB. Among FB, large firms (with 250-499 employees) and those employing 100-249 employees achieved higher (than average) product innovation indicators. Interestingly, the highest number of implemented innovations (10.5) was declared by FB respondents, representing the six largest firms, employing 500 and more workers.

\section{Table 3.}

Quantitative characteristics of business process innovations implemented in family and nonfamily firms

\begin{tabular}{|l|r|r|r|r|r|r|r|r|r|r|}
\hline $\begin{array}{l}\text { The number } \\
\text { of implemented } \\
\text { innovations }\end{array}$ & FB/MP & FB/L & FB/MS & FB/IC & FB/AM & $\begin{array}{l}\text { NFB } \\
\text { MP }\end{array}$ & $\begin{array}{l}\text { NFB } \\
\text { L }\end{array}$ & $\begin{array}{l}\text { NFB } \\
\text { MS }\end{array}$ & $\begin{array}{l}\text { NFB } \\
\text { IC }\end{array}$ & $\begin{array}{l}\text { NFB } \\
\text { AM }\end{array}$ \\
\hline No implementation & 23 & 25 & 17 & 16 & 41 & 22 & 30 & 16 & 19 & 31 \\
\hline 1 & 31 & 21 & 21 & 35 & 28 & 34 & 24 & 26 & 30 & 40 \\
\hline 2 & 30 & 55 & 49 & 36 & 41 & 32 & 55 & 41 & 33 & 35 \\
\hline $3-5$ & 56 & 32 & 34 & 31 & 34 & 51 & 29 & 35 & 37 & 32 \\
\hline $6-10$ & 17 & 24 & 26 & 20 & 15 & 17 & 20 & 30 & 26 & 16 \\
\hline $11-20$ & 4 & 5 & 6 & 13 & 2 & 12 & 10 & 19 & 20 & 13 \\
\hline More than 20 & 3 & 2 & 11 & 13 & 3 & 2 & 2 & 3 & 5 & 3 \\
\hline $\begin{array}{l}\text { The total number } \\
\text { of firms that } \\
\text { implemented } \\
\text { innovations }\end{array}$ & 141 & 139 & 147 & 148 & 123 & 148 & 140 & 154 & 151 & 139 \\
\hline
\end{tabular}

Description: MP - manufacturing process innovations; L - logistics and distribution innovations;

MS - marketing and sales innovations; IC - information and communication innovations; AM - administration and management innovations.

Source: own elaboration.

Similarly, higher (than average) product innovation indicators per firm were established for large NFB (more than 250 workers). Some differences in FB and NFB innovation, measured with the number of business process innovations, were revealed. In FB, the indicator was above the average in firms operating in the manufacturing sector and with a mixed profile. In addition, it increased with the size of the firm. Similar patterns were observed for NFB, i.e. the highest innovation indicator in manufacturing firms and an increase in the indicator corresponding to a higher firm's size. The lowest process innovation indicator was established for microfirms, both FB and NFB. The final characteristic of firms - their age - also differentiates the level of innovation of the respondent firms: in NFB, it increases with age. In FB, firms existing up to 10 years had the lowest rate, while those existing for 21-30 years - the highest. 
The survey also examined the subjective evaluation of the effects of the implementation of innovations by the management in FB and NFB (opinions on to what extent the innovations fulfilled the expectations of the management and/or owners of the firm to improve business performance - sales and/or profit). First, the analysis of the data in Table 1 reveals no significant differences in such opinions in FB and NFB. Second, the average (expressed on a 5-point scale) did not exceed 3.0, which means that the respondents declared that the implementation of the innovations did not meet (either "fully" -5 or "to a significant extent" -4 ) the expectations of the management/owners to improve business performance or were not able to determine the actual effects of the implemented innovations. The mean for product innovations in the entire sample was 2.5 (on a 5-point scale), while for business process innovations it was slightly higher and stood at 2.9 (Table 4).

Table 4.

Descriptive statistics for the entire sample of firms $(N=334)$

\begin{tabular}{|l|c|c|c|c|}
\hline \multicolumn{1}{|c|}{ Variable } & Minimum & Maximum & Mean & $\begin{array}{c}\text { Standard } \\
\text { deviation }\end{array}$ \\
\hline $\begin{array}{l}\text { 1. The evaluation of the effects of the } \\
\text { implementation of product innovations } *\end{array}$ & 1.00 & 4.00 & 2.5 & .61 \\
\hline $\begin{array}{l}\text { 2. The evaluation of the effects of the } \\
\text { implementation of business process innovations }\end{array}$ & 1.00 & 5.00 & 2.9 & .83 \\
\hline
\end{tabular}

* the number of valid responses: 288 .

Source: own elaboration.

Regardless of a business profile, size and age, the mean was at a similar level for product innovations in both FB and NFB and it is low -2.6 for FB and 2.5 for NFB. On the other hand, in the case of business process innovations, the average evaluation of the effects of these innovations for all FB and NFB was slightly higher (but does not exceed "3"). The average evaluation of the effects of process innovations was more varied according to the respondents' characteristics and in some cases exceeded the value of "3". Both in FB and NFB with a manufacturing profile, the values stood at 3.1 and 3.3, while, for example, the respective values for large firms (with 250-499 employees) were 3.5 and 3.5. It is also notable that the differences in the evaluation of the effects of implemented innovations, both product and business process related, were small, as indicated by the value of standard deviation (the smaller its value, the closer the opinions are to the mean) (see Table 4).

\section{Discussion}

The most important conclusions from the survey amount to the following: First, no significant differences in the level of innovation measured according to the Oslo methodology standards (Oslo Manual, 2018), i.e. with the number of product innovations, 
were identified in the sample. Some variation was observed in the number of business process innovations in the last three years - NFB implemented more such innovations. The research results indicate that the characteristics of family businesses are not evidently reflected in the level of their innovation (especially product innovation) - compared to non-family businesses. The results of studies conducted around the world, reviewed in the first part of the article, do not conclusively answer the question whether familiness significantly determines innovation of family businesses, giving rise to differences with non-family businesses in this respect. Although the results of the survey on innovation of Polish FB and NFB do not provide an unequivocal answer to the question posed, neither do they contradict the results of other studies (Classen et al., 2014; Kammerlander, and van Essen, 2017), especially those that point to certain FB characteristics that have a positive or negative impact on innovation. The impact of negative characteristics that may affect innovation can be compensated with the characteristics that have a positive influence on FB innovation. The analysis of the research results should also address the question whether this absence of differences with regard to product innovations may be the result of the measurement method applied. Innovation research - as discussed in the introduction - uses a variety of measures, often broken down into input (e.g. innovation expenditure, R\&D expenditure) and output (e.g. sales of new products). Moreover, the study did not apply the division of innovations into two important categories: radical and incremental, so we do not have any knowledge about the qualitative aspects of innovations implemented in the respondent firms. We also have to remember about paradoxes so characteristic of FB. Researchers emphasize that family businesses are inherently characterized by paradoxes that are manifested in tensions between the desire to preserve tradition and the need to make changes, between the expected standard of living for the family and the growth of the firm, or between the founder's wish to retain control and the successor's aspiration of autonomy, which can both hinder and foster innovation, affecting the level of FB innovation (Ingram et al., 2016).

Second, the characteristics such as a business profile and age have little impact on the differences in the level of innovation in FB and NFB, measured with the number of product innovations. A higher innovation indicator was observed in manufacturing firms and firms conducting mixed activity. In addition, greater differences were identified with respect to business process innovations - as compared to product innovations. The survey confirms that the size of firms is the factor which positively influences their innovation, which - in the case of Poland - is confirmed by the data of Statistics Poland and the reports published by the Polish Agency for Enterprise Development.

Third, the subjective opinions on the extent to which the implementation of innovations fulfilled the expectations of the management/owners of improved business performance (sales and/or profit) turned out to be very "averaged" and relatively low, as the averages did not exceed 3.0 (at low values of standard deviation, i.e. low response variation from the average). This question indirectly concerned the relationship between innovation and firm performance, 
otherwise confirmed as positive by studies into the links between innovation and performance, regardless of what performance measures are used (Rosenbusch, Brinckmann and Bausch, 2011). However, some studies show that, for example, the character of the sector may decide whether a product innovation will have a positive impact on a firm's growth or not (cf. Fuetsch and Suess-Reyes, 2017). Moreover, some research results do not confirm the positive impact of selected innovations (e.g. a new market entry) on family business performance (Alberti and Pizzurno, 2013).The subjective opinions on whether innovations fulfilled the expectations of management/owners may indirectly reflect rather moderate motivation to implement the innovations, ultimately determining the number (and type) of innovations implemented by a firm, which, according to research, is not high. Additionally, poor opinions may result from the lack of precise knowledge of the respondents about the effects of the innovations implemented in their firm, which prompted a "hard to say" answer. Lack of knowledge may be caused by lack of in-depth analyses accompanying the implementations, especially in the case of product innovations, hence the opinions may only be intuitive. Business process innovations may be more difficult to evaluate as fulfilling the expectations or not for other reasons, too. The effects of some implementations are frequently "observed" only after they accumulated, which may be related to a number of additional conditions, or it takes more time, going beyond the research horizon, for these effects to occur ${ }^{5}$. Low opinions expressed by the respondents with regard to the expected impact of innovations on improved business performance may also be a result of excessive, perhaps unrealistic expectations in this respect, and may even point to irregularities in the process of innovation development and implementation. It seems particularly difficult to explain why management/owners expressed such low opinions concerning the fulfillment of their expectations of improved business performance as a result of innovation implementations, especially that the number of such implementations is relatively low: on average one innovation per firm per year. Moreover, the opinions in FB are only marginally higher than in NFB, which may contradict the idea that the former engage in innovation activity with great caution, making the most efficient use of their resources (Duran et al., 2016; De Massis et al., 2018). Generally, the implementation of any type of innovation can generate effects over a longer period of time, going beyond the time horizon of the study.

\section{Summary}

This comparative study on FB and NFB innovation fills a gap in the area where knowledge concerning this issue is still scarce in Poland. It did not reveal any significant differences in the level of product innovation of the respondent firms, although innovation was expected to be

\footnotetext{
${ }^{5}$ For example, the purchase of modern software for one area of a firm's operations will bring the expected benefits if The implementation of IT solutions will also embrace other interconnected processes.
} 
lower in FB, as some world studies argue. FB turned out to be less innovative in terms of process innovation. Although family firms have a number of strengths that can potentially foster innovation, studies comparing FB and NFB innovation do not provide conclusive results, which implies that FB may be both more and less innovative (De Massis et al., 2015; Fuetsch, and Suess-Reyes, 2017) or such differences may not exist at all. Family businesses have to face a number of contradictions and paradoxes resulting from the combination of two separate systems: family and business, which are driven by different logics. These contradictions can complicate innovation processes and contribute to their complexity, different degrees of family commitment and different effects. Further comparative research should therefore be pursued, but it should use other measures of innovation and innovation should be divided into at least two additional categories: radical and incremental. It also seems necessary to complement quantitative surveys with qualitative studies.

The study confirms a relatively low level of innovation of the respondent firms (especially product innovations) and, according to the respondents' opinions, the expectations of management and/or owners regarding the impact of innovations on improved business performance fail to be fulfilled. These poor opinions of innovation effects are a cause for concern for a number of reasons, but mainly because they may discourage innovation activity. Certainly, the results in this area inspire continued exploration of innovation activity of firms, especially relating to the organization of the innovation process and the analysis and measurement of its effectiveness: do firms evaluate the effectiveness of innovations they implemented and how do they do it?

What implications could such research have for practice - for FB managers/owners and politicians? Studies show that FB are not less innovative when it comes to implementing new or modified products and services. This contradicts both the opinions and some research results about the conservatism of FB or their stronger orientation towards family goals at the expense of a firm's growth. It seems that the results concerning the poor opinions on the expected effects of implemented innovations should encourage entrepreneurs to reflect on the problem, analyze the expected effects of a particular type of innovation as well as carefully assess the results actually achieved - including the impact of the time factor.

\section{Acknowledgements}

The author wishes to thank Prof. Tomasz Ingram for his contribution to the analysis of the empirical research results. 


\section{References}

1. Ahluwalia, S., Mahto, R.V., and Walsh, S.T. (2017). Innovation in small firms: Does family vs. non-family matter? Journal of Small Business Strategy, 27(3), 39-49.

2. Alberti, F.G., and Pizzurno, E. (2013). Technology, innovation and performance in family firms. International Journal of Entrepreneurship and Innovation Management, 17(1-3), 142-161. https://doi.org/10.1504/IJEIM.2013.055253.

3. Bendig, D., Foege, J.N., Endriß, S., and Brettel, M. (2020). The Effect of Family Involvement on Innovation Outcomes: The Moderating Role of Board Social Capital. Journal of Product Innovation Management, 37(3), 249-272. https://doi.org/10.1111/ jpim. 12522 .

4. Chrisman, J.J., Chua, J.H., De Massis, A., Frattini, F., and Wright, M. (2015). The ability and willingness paradox in family firm innovation. Journal of Product Innovation Management, 32(3), 310-318. https://doi.org/10.1111/jpim.12207.

5. Chua, J.H., Chrisman, J.J., and Sharma, P. (1999). Defining the family business by behavior. Entrepreneurship theory and practice, 23(4), 19-39. https://doi.org/ $10.1177 \% 2 \mathrm{~F} 104225879902300402$.

6. Classen, N., Carree, M., Van Gils, A., and Peters, B. (2014). Innovation in family and nonfamily SMEs: an exploratory analysis. Small Business Economics, 42(3), 595-609. https://doi.org/10.1007/s11187-013-9490-z.

7. De Massis, A., \& Foss, N.J. (2018). Advancing family business research: The promise of microfoundations. Family Business Review, 31(4), 386-396. doi:10.1177/ 0894486518803422.

8. De Massis, A., and Foss, N.J. (2018). Advancing family business research: The promise of microfoundations. Family Business Review, 31(4), 386-396. https://doi.org/ $10.1177 \% 2 F 0894486518803422$.

9. De Massis, A., Audretsch, D., Uhlaner, L., and Kammerlander, N. (2018). Innovation with Limited Resources: Management Lessons from the German Mittelstand. Journal of Product Innovation Management, 35(1), 125-146. https://doi.org/10.1111/jpim.12373.

10. De Massis, A., Di Minin, A., and Frattini, F. (2015). Family-Driven Innovation: Resolving the Paradox in Family Firms. California Management Review, 58(1), 5-19. https://doi.org/10.1525\%2Fcmr.2015.58.1.5.

11. De Massis, A., Frattini, F., and Lichtenthaler, U. (2013). Research on technological innovation in family firms: Present debates and future directions. Family Business Review, 26(1), 10-31. https://doi.org/10.1177\%2F0894486512466258.

12. Duran, P., Kammerlander, N., van Essen, M., and Zellweger, T. (2016). Doing more with less: Innovation input and output in family firms. Academy of Management Journal, 59(4), 1224-64. https://doi.org/10.5465/amj.2014.0424. 
13. Fuetsch, E., and Suess-Reyes, J. (2017). Research on innovation in family businesses: are we building an ivory tower? Journal of Family Business Management. 7(1), 44-92. https://doi.org/10.1108/JFBM-02-2016-0003.

14. Habbershon, T.G., and Williams, M.L. (1999). A resource-based framework for assessing the strategic advantages of family firms. Family Business Review, 12(1), 1-25. doi:10.1111/j.1741-6248.1999.00001.x.

15. Ingram, A.E., Lewis, M.W., Barton, S., and Gartner, W.B. (2016). Paradoxes and innovation in family firms: The role of paradoxical thinking. Entrepreneurship Theory and Practice, 40(1), 161-176. https://doi.org/10.1111\%2Fetap.12113.

16. Jaskiewicz, P., Combs, J.G., and Rau, S.B. (2015). Entrepreneurial legacy: Toward a theory of how some family firms nurture transgenerational entrepreneurship. Journal of Business Venturing, 30(1), 29-49. https://doi.org/10.1016/j.jbusvent.2014.07.001.

17. Kammerlander, N., and van Essen, M. (2017). Family firms are more innovative than other companies. Harvard Business Review, January 25.

18. Klein, S.B. (2000). Family business in Germany: significance and structure. Family Business Review, 13(3), 157-182.

19. Kraśnicka, T., and Głód, G. (2018). Związki pomiędzy innowacyjnością a wynikami firm rodzinnych. Przedsiębiorczość i Zarządzanie, 19(6), cz. 2, Konkurencyjność wspótczesnych przedsiębiorstw-modele, koncepcje i uwarunkowania), 309-323.

20. Kraśnicka, T., Głód, W., Wronka-Pośpiech, M. (2018). Management innovation, proinnovation organisational culture and enterprise performance: testing the mediation effect. Review of Managerial Science, 12(3), 737-769.

21. Kraśnicka, T., Ingram, T., Głód, G. (2019). Rodzinność polskich przedsiębiorstwstymulator czy przeszkoda innowacyjności. Przegląd Organizacji, 7, 22-31.

22. Kraśnicka, T., Steinerowska-Streb, I. (2019). Family involvement, and innovation of family enterprises. Organization \& Management, Zeszyty Naukowe Politechniki Ślaskiej, Sería: Organizacja i Zarzadzanie,136, 289-303.

23. Matzler, K., Veider, V., Hautz, J., and Stadler, Ch. (2015). The Impact of Family Ownership, Management, and Governance on Innovation. Journal of Product Innovation Management, 32(3), 319-333. https://doi.org/10.1111/jpim.12202.

24. Naldi, L., Cennamo, C., Corbetta, G., and Gomez-Mejia, L. (2013). Preserving socioemotional wealth in family firms: Asset or liability? The moderating role of business context. Entrepreneurship Theory and Practice, 37(6), 1341-1360. https://doi.org/ 10.1111\%2Fetap. 12069.

25. Neubaum, D. (2018). Family business research: Roads travelled and the search for unworn paths. Family Business Review, 31, 259-270. https://doi.org/ $10.1177 \% 2 \mathrm{~F} 0894486518792948$. 
26. OECD Publishing (2018). Oslo Manual 2018: Guidelines for collecting, reporting and using data on innovation. Organisation for Economic Co-operation and Development OECD.

27. Pichlak, M. (2012). Uwarunkowania innowacyjności organizacji. Studium teoretyczne $i$ wyniki badań empirycznych. Warszawa: Difin.

28. Podręcznik Oslo (2008). Zasady gromadzenia $i$ interpretacji danych dotyczacych innowacji. OECD, EUROSTAT, 2005. Warszawa: Ministerstwo Nauki i Szkolnictwa Wyższego, Departament Strategii i Rozwoju Nauki.

29. Reay, T., Jaskiewicz, P., \& Hinings, C.R. (2015). How family, business, and community logics shape family firm behavior and "rules of the game" in an organizational field. Family Business Review, 28(4), 292-311. https://doi.org/10.1177\%2F0894486515577513.

30. Roessl, D., Fink, M., and Kraus, S. (2010). Are family firms fit for innovation? Towards an agenda for empirical research. International Journal of Entrepreneurial Venturing, 2(3-4), 366-380. https://doi.org/10.1504/IJEV.2010.037118.

31. Rondi, E., De Massis, A., and Kotlar, J. (2019). Unlocking innovation potential: A typology of family business innovation postures and the critical role of the family system. Journal of Family Business Strategy, 10(4), 100236. https://doi.org/10.1016/j.jfbs.2017.12.001.

32. Rosenbusch, N., Brinckmann, J., and Bausch, A. (2011). Is innovation always beneficial? A meta-analysis of the relationship between innovation and performance in SMEs. Journal of Business Venturing, 26(4), 441-457. https://doi.org/10.1016/j.jbusvent.2009.12.002.

33. Safin, K. (2007). Przedsiębiorstwa rodzinne - istota i zachowania strategiczne. Wrocław: Wydawnictwo AE.

34. Steeger, J.H., and Hoffmann, M. (2016). Innovation and family firms: ability and willingness and German SMEs. Journal of Family Business Management. 6(3), 251-269. https://doi.org/10.1108/JFBM-09-2015-0036.

35. Steinerowska-Streb, I. (2015). Bariery finansowe w działalności polskich przedsiębiorstw rodzinnych. In: B. Piasecki, A. Marjański (eds.), Przedsiębiorczość i Zarządzanie. Firmy rodzinne - doświadczenia i perspektywy zarzadzania, tom XVI, zeszyt 7, część II, 351-369.

36. Sułkowski, Ł., and Marjański, A. (2009). Firmy rodzinne, jak osiagnać sukces w sztafecie pokoleń. Warszawa: Wydawnictwo Poltex.

37. Surdej, A., and Wach, K. (2010). Przedsiębiorstwa rodzinne wobec sukcesji. Warszawa: Difin. 